\title{
Nitrogen Fertilizer Management Practices to Enhance Seed Production by 'Anaheim Chili' Peppers
}

\author{
J.O. Payero' and M.S. Bhangoo ${ }^{2}$ \\ Califomia Agricultural Technology Institute, California State University, Fresno, CA 93740
}

J.J. Steiner ${ }^{3}$

National Forage Seed Production Research Center, Agricultural Research Service, U.S. Department of Agriculture, 3450 SW Campus Way, Oregon State University, Corvallis, OR 97331

Additional index words. Capsicum annuиm var. annuum, reproductive development, pure-live seed, seed germination, nitrogen-use efficiency, petiole nitrate-nitrogen

\begin{abstract}
The effects of six applied $\mathrm{N}$ treatments differing by rates and frequencies of application on the yield and quality of pepper (Capsicum annuum var. annuum $\mathbf{L}$. 'Anaheim Chili') grown for seed was studied. The timing of $\mathbf{N}$ applications was based on crop phenology, leaf petiole nitrate-nitrogen concentrations $\left(\mathrm{NO}_{3}\right.$-N) minimum thresholds, and scheduled calendar applications of fixed amounts of $\mathrm{N}$. Solubilized $\mathrm{NH}_{4} \mathrm{NO}_{3}$ was applied through a trickleirrigation system to ensure uniform and timely applications of $\mathrm{N}$. Rate of mature (green and red) fruit production was unaffected by any treatment except weekly applications of $28 \mathrm{~kg} \cdot \mathrm{ha}^{-1}$ of $\mathrm{N}$, which stopped production of mature fruit before all other treatments. Early season floral bud and flower production increased with increasing amounts of $\mathbf{N}$. The two highest total $\mathbf{N}$ treatments produced more floral buds and flowers late in the season than the other treatments. Total fruit production was maximized at $240 \mathrm{~kg} \mathrm{~N} / \mathrm{ha}$. Differences in total fruit production due to frequency of $\mathbf{N}$ application resulted at the highest total $\mathbf{N}$ level. Red fruit production tended to be maximized with total seasonal applied $\mathrm{N}$ levels of $240 \mathrm{~kg} \cdot \mathrm{ha}^{-1}$ and below, although weekly applications of $\mathrm{N}$ reduced production. Total seed yield was a function of red fruit production. Pure-1ive seed (PLS) production was a function of total seed production. Nitrogen use efficiency (NUE) for red fruit production also decreased with $\mathbf{N}$ rates $>240 \mathrm{~kg}^{-1} \mathrm{ha}^{-1}$, but PLS yield and NUE decreased in a near-linear fashion as the amount of total seasonal applied $\mathrm{N}$ increased, regardless of application frequency. Season average $\mathrm{NO}_{3}-\mathrm{N}\left(\mathrm{AVE} \mathrm{NO}_{3}-\mathrm{N}\right)$ values $>4500 \mathrm{mg} \cdot \mathrm{kg}^{-1}$ had total seed and PLS yields less than those treatments $<4000 \mathrm{mg} \cdot \mathrm{kg}^{-1}$. Six-day germination percentage was reduced with weekly N applications of $14 \mathrm{~kg} \cdot \mathrm{ha}^{-1}$. Seed mass was reduced with weekly $N$ applications of $28 \mathrm{~kg} \cdot \mathrm{ha}^{-1}$. Final germination percent, seedling root length and weight, and field emergence were unaffected by any of the $N$ treatments. These findings indicate that different $\mathbf{N}$ management strategies are needed to maximize seed yield compared to fruit yield and, therefore, there may be an advantage to growing 'Anaheim Chili' pepper specifically for seed.
\end{abstract}

It is well-established that $\mathrm{N}$ influences the growth and development of pepper grown for fruit. This effect-depends on the available $\mathrm{N}$ in the soil and on the amount of applied $\mathrm{N}$ (Cochran, 1936; Maynard et al., 1962; O'Sullivan, 1979; Panpruik et al., 1982; Piazza and Venturi, 1971; Relwani, 1963; Somos et al., 1976; Stroehlein and Oebker, 1979; Sundstrom et al., 1984). However, results are related to production region. Maximum fruit production has been achieved with applications as low as 70 kg.ha' (O'Sullivan, 1979) to as high as $224 \mathrm{~kg} \cdot \mathrm{ha}^{-1}$ (Locascio and Fiskell, 1977).

Recommendations for $\mathrm{N}$ fertilization of peppers grown in California are 170-225 kg.ha' (Sims and Smith, 1984). 'Anaheim Chili' peppers respond to 224 and $336 \mathrm{~kg} \cdot \mathrm{ha}^{-1}$ depending on the amount of $\mathrm{N}$ already present in the soil (Ririe, 1977). Depending on specific location conditions, commercial producers of 'Anaheim Chili' peppers in California use between 56 and $336 \mathrm{~kg} \cdot \mathrm{ha}^{-1}$ (C. Mouwen, personal communication, 1989).

Received for publication 5 June 1989. Contribution of California Agricultural Technology Institute, California State Univ., Fresno, and USDA/ARS. California Agricultural Technology Institute technical paper no. 900605. This study was supported in art by a grant from Gentry Foods Corporation. Mention of trade names in this publication does not imply endorsement by California State Univ. or USDA/ARS. The cost of publishing this paper was defrayed in part by the payment of page charges. Under postal regulations, this paper therefore must be hereby marked advertisement solely to indicate this fact.

'Forrner Graduate Research Assistant.

${ }^{2}$ Professor. Dept. of Plant Science and Mechanized Agriculture, California State Univ., Fresno, CA 93740.

${ }^{3}$ Research Agronomist.
Use of plant tissue $\mathrm{N}$ concentrations provides a means to evaluate the $\mathrm{N}$ nutrient status and effectiveness of applied $\mathrm{N}$ in relationship to that available in the soil. Several accounts relate plant tissue $\mathrm{N}$ concentration in pepper to plant growth, development, and fruit maturity. These reports are difficult to compare because different plant parts were sampled for total $\mathrm{N}$ or $\mathrm{NO}_{3}-\mathrm{N}$ analysis. Young leaves and leaf petioles tend to contain higher $\mathrm{NO}_{3}-\mathrm{N}$ than older leaves and other plant parts. Additionally, varying plant tissue $\mathrm{NO}_{3}-\mathrm{N}$ were obtained with similar amounts of applied $\mathrm{N}$, indicating that different amounts of $\mathrm{N}$ were available to the crop from the soil $\mathrm{N}$ reserve in addition to the applied N. Also, geographical location appears to greatly influence the findings. Thus, Thomas and Heilman (1964) reported that, under greenhouse conditions, the critical total leaf $\mathrm{N}$ concentration (including $\mathrm{NO}_{3}-\mathrm{N}$ ) was $40,000 \mathrm{mg} \cdot \mathrm{kg}^{-1}$ Lorenz and Tyler (1983) in California specified deficient and sufficient leaf petiole $\mathrm{NO}_{3}-\mathrm{N}$ that relate to early growth (first bloom), early fruit set, and full fruit size. The recommended ranges were 5000-7000, 1000-1500, and 750-1000 $\mathrm{mg} \cdot \mathrm{kg}^{-1}$, respectively. Another report from California showed that 224 to $336 \mathrm{~kg} \cdot \mathrm{ha}^{-1}$ of applied $\mathrm{N}$ was required to meet these recommended leaf petiole $\mathrm{NO}_{3}-\mathrm{N}$ levels (Ririe, 1977). In Arizona, stem tissue $\mathrm{NO}_{3}$ $\mathrm{N}$ of $8000-10,000 \mathrm{mg} \cdot \mathrm{kg}^{-1}$ at heavy fruit set were reported not sufficient to produce high yields of fruit. This level was achieved with a minimum of $100 \mathrm{~kg}$ applied N/ha. Nitrogen deficiency was noted when $\mathrm{NO}_{3}-\mathrm{N}$ fell below $2000 \mathrm{mg} \cdot \mathrm{kg}^{-1}$ (Stroehlein and Oebker, 1979). Panpruik et al. (1982) indicated that leaf petiole $\mathrm{NO}_{3}-\mathrm{N}$ should be maintained at $4000 \mathrm{mg} \cdot \mathrm{kg}^{-1}$ through 
mid-season to avoid fruit yield reductions in New Mexico. O'Sullivan (1979) in Ontario, Canada, showed that fruit yields were reduced when leaf petiole $\mathrm{NO}_{3}-\mathrm{N}$ fell below $4000 \mathrm{mg} \cdot \mathrm{kg}^{-1}$. This level was achieved with 35 to $70 \mathrm{~kg} \cdot \mathrm{ha}^{-1}$. Thomas and Heilman (1967) reported from Texas that total plant dry matter production was restricted below $40,000 \mathrm{mg} \cdot \mathrm{kg}^{-1}$ as a result of $<134 \mathrm{~kg} \cdot \mathrm{ha}^{-1}$ of $\mathrm{N}$ being applied before planting.

Little research has been done to determine the effects of $\mathrm{N}$ fertility on the yield and quality of pepper grown for seed. Gill et al. (1974) reported that an increase in applied $\mathrm{N}$ from 0 to $370 \mathrm{~kg} \cdot \mathrm{ha}^{-1}$ did not produce a proportional increase in seed yield. Since the production of seed is not of concern when producing market fruit, it is important to understand the effects of $\mathrm{N}$ fertilization on pepper grown specifically for seed. Much of the 'Anaheim Chili' pepper seed produced is a bypass product from commercial food product processing (C. Mouwen, personal communication). This study was undertaken to determine the effect of $\mathrm{N}$ treatments on the reproductive development and seed production of 'Anaheim Chili' peppers grown specifically for seed. The treatments used were based on crop phenology, leaf petiole $\mathrm{NO}_{3}-\mathrm{N}$ minimum thresholds, or calendar application schedules of fixed $\mathrm{N}$ amounts.

\section{Materials and Methods}

Field experiment and analyses. The study was conducted on a Hanford sandy loam soil (coarse-loamy, mixed, thermic Typic Xerothent) at California State Univ., Fresno. The experimental area had been uniformly cropped with carrot grown for seed the previous season. 'Anaheim Chili' pepper seeds were planted 16 May 1986 (day 136) in two rows $20 \mathrm{~cm}$ apart on preshaped 1m-wide beds. Each plot consisted of four beds $14 \mathrm{~m}$ long. The experimental area was sprinkle-irrigated until seedling emergence. The plants were thinned to $25 \mathrm{~cm}$ within each planting row on 11 June (day 162). Irrigation water was then applied by a Netafim drip irrigation system (Fresno, Calif.) consisting of laterals placed on the center of each bed with in-line, turbulentflow emitters spaced every $50 \mathrm{~cm}$ along the lateral, each discharging 2 liters $\cdot \mathrm{hr}^{-1}$. Water applied to each treatment was measured using 19-mm flow meters to ensure uniform water and fertilizer applications to the various treatments. Irrigation water was applied when tensiometer readings were between 0.030 and $0.035 \mathrm{mPa}$ at $40-\mathrm{cm}$ soil depth, about every 5 to 7 days, depending on the weather.

A blanket application of $30 \mathrm{~N}-90 \mathrm{P}_{2} \mathrm{O}_{5}-112 \mathrm{~K}_{2} \mathrm{O}\left(\mathrm{kg} \cdot \mathrm{ha} \mathrm{a}^{-1}\right)$ in a concentrated stock solution was made 13 June (day 164) through the trickle-irrigation system. Six applied $\mathrm{N}$ treatments in the form of $\mathrm{NH}_{4} \mathrm{NO}_{3}$, which differed by rates and frequencies of application, were replicated four times (Table 1). The treatments were based on crop phenology $\left(70-3 \mathrm{X}=70 \mathrm{~kg} \cdot \mathrm{ha}^{-1}\right.$ at establishment, early fruit set, and full fruit size); leaf petiole $\mathrm{NO}_{3}-\mathrm{N}$ minimum thresholds $\left(35-5 \mathrm{~K}=35 \mathrm{~kg} \cdot \mathrm{ha}^{-1}\right.$ whenever $\mathrm{NO}_{3}-\mathrm{N}$ decreased to $5000 \mathrm{mg} \cdot \mathrm{kg}^{-1} ; 35-2 \mathrm{~K}=35 \mathrm{~kg} \cdot \mathrm{ha}^{-1}$ whenever $\mathrm{NO}_{3}-\mathrm{N}$ decreased to $2000 \mathrm{mg} \cdot \mathrm{kg}^{-1}$; and $70-5 \mathrm{~K}=70 \mathrm{~kg} \cdot \mathrm{ha}^{-1}$ whenever $\mathrm{No}_{3}-\mathrm{N}$ decreased to $5000 \mathrm{mg} \cdot \mathrm{kg}^{-1}$ ); or fixed $\mathrm{N}$ rates applied on a calendar schedule $\left(14-\mathrm{W}=14 \mathrm{~kg} \cdot \mathrm{ha}^{-1}\right.$. week $^{-1}$ and $\left.28-\mathrm{W}=28 \mathrm{~kg} \cdot \mathrm{ha}^{-1} \cdot \mathrm{week}^{-1}\right)$. The total seasonal applied $\mathrm{N}$ for the six treattments was $240,275,170,310,170$, and 310 $\mathrm{kg} \cdot \mathrm{ha}^{-1}$, respectively. Solubilized $\mathrm{NH}_{4} \mathrm{NO}_{3}$ was injected into the irrigation system through Venturi injectors to establish the variable $\mathrm{N}$ treatments. The amounts of total applied $\mathrm{N}$ corresponded with a range commonly used for 'Anaheim Chili' peppers grown in California.

Fifty leaf petioles from fully expanded young leaves (Lorenz
Table 1. Dates and amounts of six applied $\mathrm{N}$ treatments to 'Anaheim Chili' pepper grown for seed at Fresno, Calif., in 1986.

\begin{tabular}{|c|c|c|c|c|c|c|c|c|c|c|c|c|}
\hline \multirow[b]{2}{*}{ Treatment $^{z}$} & \multicolumn{12}{|c|}{ Day of year of application } \\
\hline & 164 & 184 & 191 & 198 & 205 & 212 & 219 & 226 & 233 & 241 & 247 & Total \\
\hline \multicolumn{13}{|c|}{$\left(k g \cdot h a^{-1}\right)$} \\
\hline $70-3 X$ & 30 & 70 & & & & 70 & & & 70 & & & 240 \\
\hline $35-5 K$ & 30 & 35 & & 35 & 35 & & 35 & 35 & & 35 & 35 & 275 \\
\hline $35-2 \mathrm{~K}$ & 30 & & 35 & & 35 & & & 35 & & & 35 & 170 \\
\hline $70-5 \mathrm{~K}$ & 30 & 70 & & 70 & & & 70 & & & & 70 & 310 \\
\hline $14-W$ & 30 & 14 & 14 & 14 & 14 & 14 & 14 & 14 & 14 & 14 & 14 & 170 \\
\hline $28-W$ & 30 & 28 & 28 & 28 & 28 & 28 & 28 & 28 & 28 & 28 & 28 & 310 \\
\hline
\end{tabular}

${ }^{2} 70-3 \mathrm{X}=70 \mathrm{~kg} \mathrm{~N} / \mathrm{ha}$ at establishment, early fruit set, and full fruit size; $35-5 \mathrm{~K}=35 \mathrm{~kg} \mathrm{~N} / \mathrm{ha}$ whenever petiole $\mathrm{NO}_{3}-\mathrm{N}$ content decreased to $5000 \mathrm{mg} \cdot \mathrm{kg}^{-1} ; 35-2 \mathrm{~K}=35 \mathrm{~kg} \mathrm{~N} / \mathrm{ha}$ whenever petiole $\mathrm{NO}_{3}-\mathrm{N}$ content decreased to $2000 \mathrm{mg} \cdot \mathrm{kg}^{-1} ; 70-5 \mathrm{~K}=70 \mathrm{~kg} \mathrm{~N} / \mathrm{ha}$ whenever petiole $\mathrm{NO}_{3}-\mathrm{N}$ content decreased to $5000 \mathrm{mg} \cdot \mathrm{kg}^{-1} ; 14-\mathrm{W}=14 \mathrm{~kg} \mathrm{~N} / \mathrm{ha}$ each week; $28-\mathrm{W}=28 \mathrm{~kg} \mathrm{~N} / \mathrm{ha}$ each week.

and Tyler, 1983) were sampled at random between 1100 and $1300 \mathrm{HR}$ from each plot about weekly from 8 July (day 189) to 27 Sept. (day 260) for $\mathrm{NO}_{3}-\mathrm{N}$ determination. One-half gram of ground material was extracted with $50 \mathrm{ml}$ of $0.1 \mathrm{M}$ aluminum sulfate for $0.5 \mathrm{hr}$. Nitrate-N concentration was determined with an ion selective electrode.

About every 14 days beginning 14 July (day 195) and ending 3 Sept. (day 247), five plants were chosen at random, uprooted, and the number of flower buds, flowers (fully opened), fruit buttons (structures formed following pollination when petal fall), and set fruit (both developing and mature) were counted for each experimental unit. At maturity (3 Oct., day 276), total fruit yield (red and green fruits, both full-sized) was obtained for a once-over harvest from $6 \mathrm{~m}$ of row from the two middle rows of each plot. Red fruits were separated from green and both were weighed. Seeds were extracted from the red fruits with a modified version of a mechanical fruit crusher (Wehner et al., 1983). The seeds were then washed with a seed cleaning sluice (Steiner and Letizia, 1986), separated into fractions that either sank or floated, and dried at $31 \mathrm{C}$ to constant weight $(\approx 10 \%$ moisture) in a forced-air seed drier. The seeds were then cleaned using a continuous flow aspirator and weighed to determine total seed yield and seed mass. Seed germination was determined according to AOSA rules (Association of Official Seed Analysts, 1978), with counts made on days 6 (early count germination) and 14 (final count germination). Pure-live seed was determined by multiplying seed yield by final count germination (Copeland and McDonald, 1985). Seedling root length and seedling dry weight were also determined. Three 100 -seed replicates from each experimental unit were seeded $1 \mathrm{~cm}$ deep and $2 \mathrm{~cm}$ apart on 1-m-wide beds on $1 \mathrm{Apr} .1987$ to determine field emergence. The area was sprinkler-irrigated daily to maintain uniform soil moisture. Final seedling emergence was determined when all emerged seedling had reached the first true leaf.

Total and red fruit, and total seed and PLS yield $\mathrm{N}$ use efficiency (NUE) were calculated as the yield of the respective components per amount of total $\mathrm{N}$ applied for each treatment.

\section{Results and Discussion}

Reproductive development. Initial flower bud production (day 195) was relatively unaffected by the different treatments (Fig. la). The number of flower buds present at day 203 was positively related to the amount of total applied $\mathrm{N}$ to that time. This result agrees with the findings of Cochran (1936) and May- 
nard et al. (1962) for a first set of fruit, although no effect was observed for the average over two harvests. Maximum flower bud and flower load (Fig. lb) was reached by the time of maximum fruit set (day 231; Fig. 1c) for all treatments except 70$5 \mathrm{~K}$, which had achieved maximum load by early fruit set (day 217). Flower bud and flower production by day 247 were greater for treatments $28-\mathrm{W}$ and $70-5 \mathrm{~K}$ (both receiving the greatest amount of total applied $\mathrm{N}$ for all treatments, $310 \mathrm{~kg} \cdot \mathrm{ha}^{-1}$, compared to all other treatments (Fig. 1 a and b). Maximum new fruit set (buttons) was achieved by day 231 for all treatments, with the rate of new fruit production decreasing after this time (Fig. 1c). The number of fruit that had set (achieved a minimum length of $2 \mathrm{~cm}$ ) continued to increase through day 247 for all treatments except $28-\mathrm{W}$, which reached maximum fruit production at day 217, the time of initial full fruit sizing (Fig. id). This was the only substantial modification in plant phenology caused by the different treatments. The weekly application of $\mathrm{N}$ at $28 \mathrm{~kg}-\mathrm{ha}^{-1}$ appeared to allow continual initiation of floral structures (Fig. 1a), but hindered further flowering (Fig. 1b) and fruit set (Fig. 1d). This finding has not been noted in other reports were high $\mathrm{N}$ levels were used, and maybe due to the high (weekly) frequency of application.

The relative equal time of initial bud formation and flowering for all treatments is in agreement with the findings of Thomas and Heilman (1967), but contrary to Gill et al. (1974), who found flowering to be delayed with increasing levels of applied $\mathrm{N}$. The initial increase in number of flower buds and flowers with increasing amount of $\mathrm{N}$ also agrees with Cochran (1932) and Thomas and Heilman (1967).

At final harvest (day 276), 70-3X produced the greatest amount of total fruit (red and green) of all the treatments (Fig. 2).
Treatment $28-\mathrm{W}$ was the lowest-yielding, with the remaining treatments being intermediate and roughly decreasing in order according to increasing frequency and amounts of applied $\mathrm{N}$. Treatment $70-5 \mathrm{~K}$, which received the same total seasonal application of $\mathrm{N}$ as $28-\mathrm{W}$, yielded more total fruit. This result indicates that frequency of application affected plant performance and that total fruit yield is not a simple function of total applied N. The decrease in fruit yield with the higher levels of $\mathrm{N}$ is in agreement with the findings of Ahmed (1984), Piazza and Venturi (1971), Thomas and Heilman (1967), and StroehIein and Oebker (1979). The absence of change in fruit yield, with differing levels of applied $\mathrm{N}$ below $210 \mathrm{~kg} \cdot \mathrm{ha}^{-1}$ agrees with O'Sullivan (1979) and Panpruik et al. (1982).

Red fruit yield was the highest for $70-3 \mathrm{X}$ and $35-2 \mathrm{~K}$ and the lowest for $28-\mathrm{W}$. Treatments $35-5 \mathrm{~K}, 70-5 \mathrm{~K}$, and $14-\mathrm{W}$ were intermediate in their responses (Fig. 2). A very weak negative relationship existed between red fruit yield and total applied $\mathrm{N}$, with maximum red fruit production at $240 \mathrm{~kg} \cdot \mathrm{ha}^{-1}$. Applications of $\mathrm{N}$ in excess of $240 \mathrm{~kg} \cdot \mathrm{ha}^{-1}$ decreased red fruit production. When $\mathrm{N}$ at $170 \mathrm{~kg} \cdot \mathrm{ha}^{-1}$ was applied in either weekly application (as in the 14-W treatment), or when petiole $\mathrm{N}$ levels were $2000 \mathrm{mg} \cdot \mathrm{kg}^{-1}$ (as in the $35-2 \mathrm{~K}$ treatment), the effects on fruit production were different. Greater red and total fruit yields were realized when $\mathrm{N}$ was applied to maintain petiole $\mathrm{NO}_{3}-\mathrm{N}$ levels >2000 $\mathrm{mg} \cdot \mathrm{kg}^{-1}$

Total and red fruit NUE decreased as the amount of applied $\mathrm{N}$ increased (Fig. 3a). Total applied $\mathrm{N}$ in excess of $240 \mathrm{~kg} \cdot \mathrm{ha}^{-1}$ reduced NUE for both fruit classes. The effect of frequency of application on total and red fruit NUE was not as clearly defined as it was for the respective component fruit production.

Seed quality. Six-day germination percent, which is a mea-
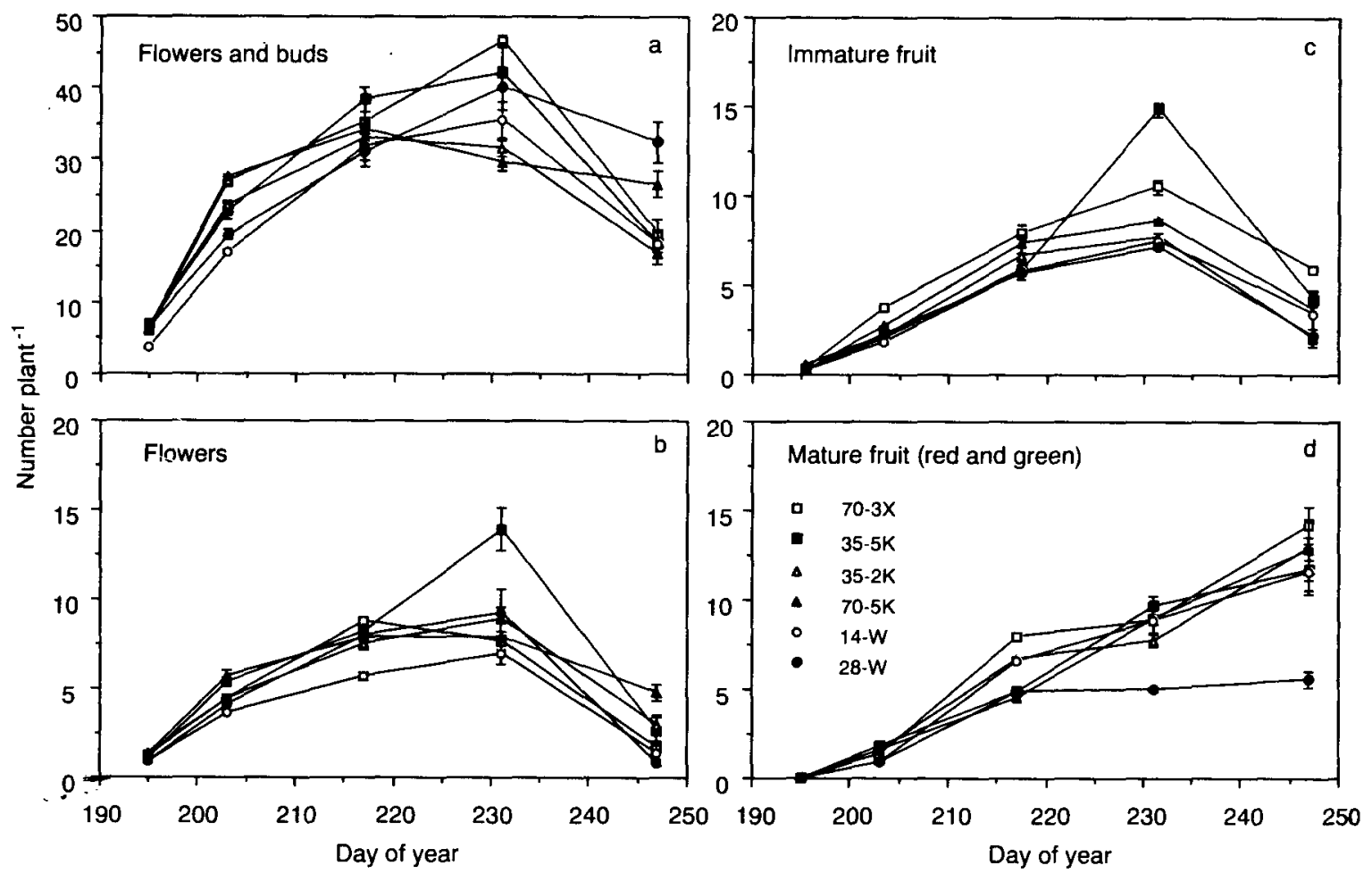

Fig. 1. Effect of six applied $\mathrm{N}$ treatments on flower bud, flower, immature, and mature truit development of 'Anaheim Chili' pepper grown for seed. Treatments: $70-3 \mathrm{X}=70 \mathrm{~kg} \mathrm{~N} / \mathrm{ha}$ at establishment, early fruit set, and full fruit size; $35-5 \mathrm{~K}=35 \mathrm{~kg} \mathrm{~N} / \mathrm{ha}^{\mathrm{w}}$ whenever petiole NO${ }_{3}$ $\mathrm{N}$ content decreased to $5000 \mathrm{mg} \cdot \mathrm{kg}^{-1} ; 35-2 \mathrm{~K}=35 \mathrm{~kg} \mathrm{~N} / \mathrm{ha}$ whenever petiole $\mathrm{NO}_{3}-\mathrm{N}$ content decreased to $2000 \mathrm{mg} \cdot \mathrm{kg}^{-1} ; 70-5 \mathrm{~K}=70 \mathrm{~kg}$ $\mathrm{N} / \mathrm{ha}$ whenever petiole $\mathrm{NO}_{3}-\mathrm{N}$ content decreased to $5000 \mathrm{mg} \cdot \mathrm{kg}^{-1} ; 14-\mathrm{W}=14 \mathrm{~kg} \mathrm{~N} / \mathrm{ha}$ each week; $28-\mathrm{W}=28 \mathrm{~kg} \mathrm{~N} / \mathrm{ha}$ each week. 


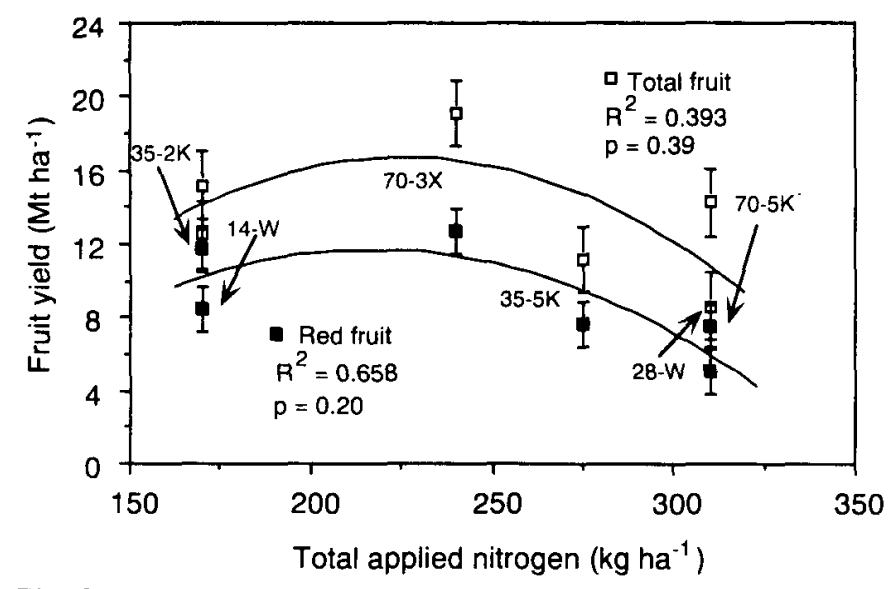

Fig. 2. Effect of total seasonal applied $\mathrm{N}$ on total and red fruit production of 'Anaheim Chili' pepper grown for seed. Legend same as Fig. 1.

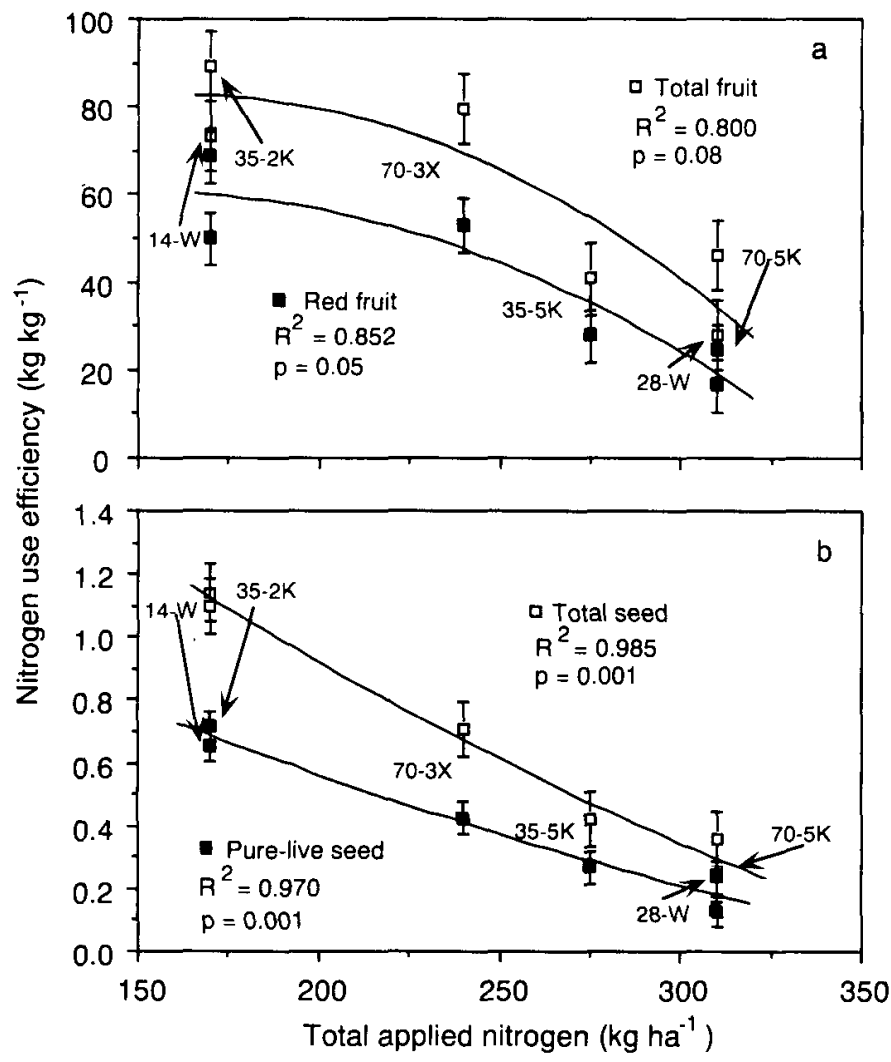

Fig. 3. Effect of total seasonal applied $\mathrm{N}$ on the $\mathrm{N}$ use efficiency of total fruit, red fruit, total seed, and pure live seed production of 'Anaheim Chili' pepper grown for seed. Legend same as Fig. 1.

sure of seedling vigor, was greatest for $70-5 \mathrm{~K}$ and $35-2 \mathrm{~K}$ but least for 14-W (Table 2). The other three treatments were intermediate in their early germination response. The frequency of application for the two highest total seasonal applied $\mathrm{N}$ treatments (28-W and 70-5K) did not affect early count germination percentages (Table 2). However, seedling dry weight, root length, and field emergence, which also are indicators of seed vigor, were not affected by the different $\mathrm{N}$ treatments. The absence of a relationship between 6-day germination percent and these other indicators of vigor suggests that $\mathrm{N}$ fertility has little if any affect
Table 2. Effect of six applied $N$ treatments on seed quality of 'Anaheim Chili' pepper grown at Fresno, Calif., in 1986.

\begin{tabular}{|c|c|c|c|c|c|c|}
\hline \multirow[b]{2}{*}{ Treatment $^{\mathbf{z}}$} & \multicolumn{2}{|c|}{$\begin{array}{c}\text { Germination } \\
(\%)\end{array}$} & \multirow{2}{*}{$\begin{array}{c}\text { Seed } \\
\text { mass } \\
(\mathrm{mg} / \mathrm{seed})\end{array}$} & \multirow{2}{*}{$\begin{array}{c}\text { Seedling } \\
\text { wt } \\
\text { (mg/seed) }\end{array}$} & \multirow{2}{*}{$\begin{array}{r}\text { Root } \\
\text { length } \\
(\mathrm{mm})\end{array}$} & \multirow{2}{*}{$\begin{array}{c}\text { Field } \\
\text { emergenc } \\
(\%)\end{array}$} \\
\hline & 6-day & 14-day & & & & \\
\hline $70-3 X$ & 50.3 & 684 & 7.0 & 3.9 & 16 & 41 \\
\hline $35-$ & & & & & 1. & \\
\hline $35-2 \mathrm{~K}$ & & & & 4 & 17 & 41 \\
\hline $70-5 \mathrm{~K}$ & 6 & 79 & 7.0 & 4. & 15 & 47 \\
\hline $14-W$ & 46 & 72 & 7.1 & 4. & 15 & 45 \\
\hline $28-W$ & 57.8 & 76.3 & 6.6 & 3.9 & 16 & 40 \\
\hline $\mathrm{LSD}_{0.05}$ & 13.6 & NS & 0.4 & NS & NS & NS \\
\hline
\end{tabular}

${ }^{2}$ Legend same as Table 1.

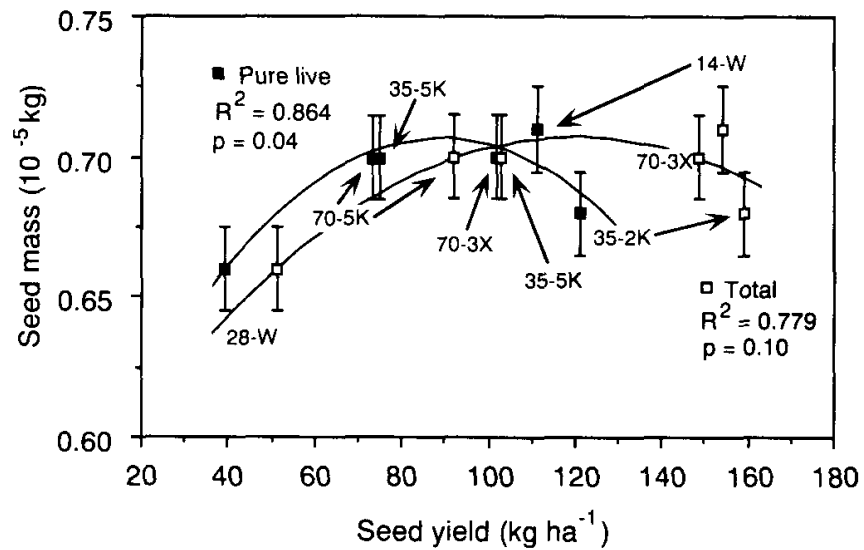

Fig. 4. Effect of total and pure live seed yield on the respective seed mass of 'Anaheim Chili' pepper grown for seed. Legend same as Fig. 1.

on seed vigor. Final germination percent (14-day) was not affected by any of the applied $\mathrm{N}$ treatments.

Seed mass was related more to PLS yield $\left(R^{2}=0.864\right)$ than total seed yield $\left(R^{2}=0.779\right)$ (Fig. 4). The $28-\mathrm{W}$ treatment produced the lightest seeds and had the lowest PLS yield of all treatments. This relationship indicates that plant $\mathrm{N}$ status affects both seed yield (see Fig. $6 \mathrm{a}$ and $\mathrm{b}$ ) and individual seed mass (Fig. 4). Since red fruit production was also greatly reduced in this treatment (Fig. 2), it appears that the weekly applications of $\mathrm{N}$ at $28 \mathrm{~kg} \cdot \mathrm{ha}^{-1}$ were detrimental to 'Anaheim Chili' pepper reproductive development.

Seed yield components and seed yield relationships. Production of red fruit (which produce viable seeds) was a linear function of total fruit yield (Fig. 5a). However, both total and PLS yields were nonlinear functions of red fruit yield and were maximized at a yield of $\approx i 8 \mathrm{t} \cdot \mathrm{ha}^{-1}$ or higher (Fig. 5b). Thus, maximum seed yields are not equated with maximum red fruit production. Since final count seed germination percent was not affected by any of the treatments, PLS production was a linear function of total seed production $\left(r^{2}=0.977 ; P=0.004\right)$. Therefore, maximum PLS yield was obtained by maximizing total seed production.

Total and PLS yields were functions of total applied N (Fig. 6a). Applied $\mathrm{N}$ rates $>240 \mathrm{~kg} \cdot \mathrm{ha}^{-1}$ resulted in decreased seed yields. Treatments $35-2 \mathrm{~K}, 14-\mathrm{W}$, and $70-3 \mathrm{X}$ produced the greatest amounts of total and pure-live seed, $28-\mathrm{W}$ produced the least, and $35-5 \mathrm{~K}$ and $70-5 \mathrm{~K}$ were intermediate in their responses. Frequency of application was important only at the 

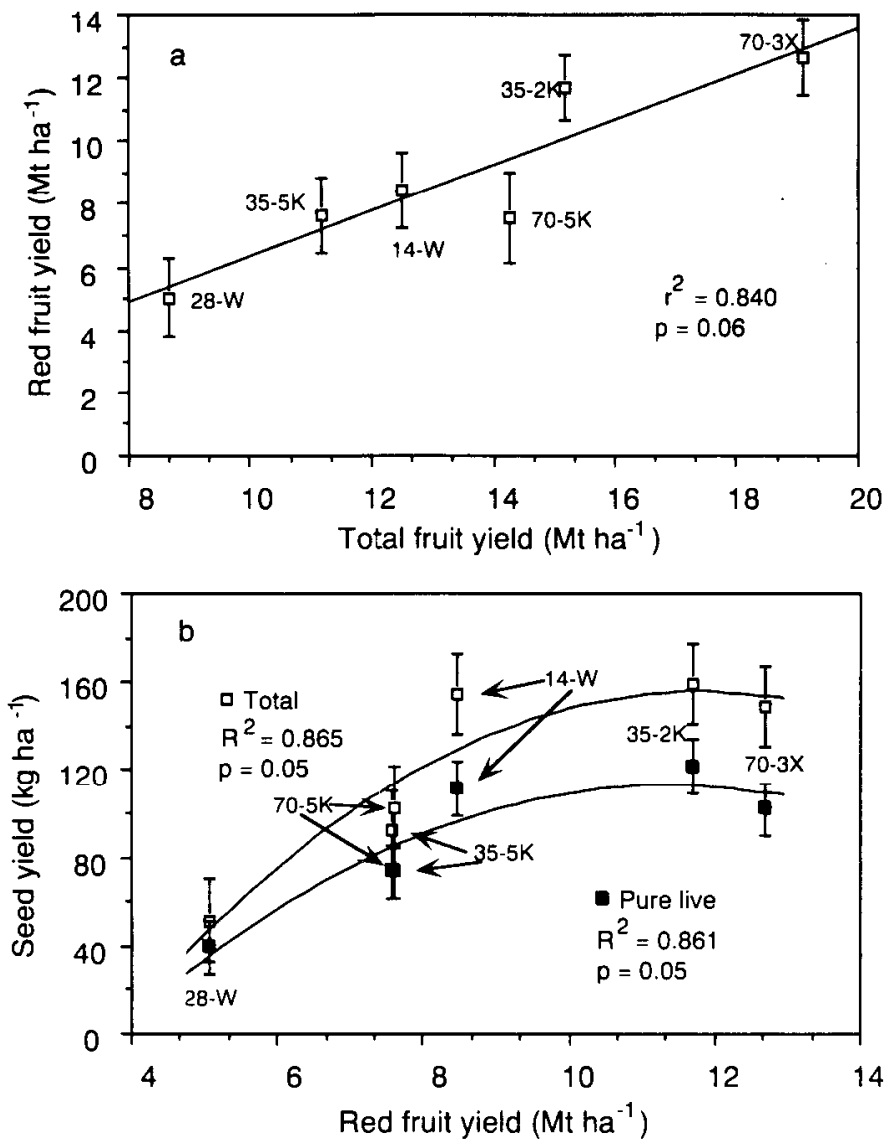

Fig. 5. Effect of total fruit yield on red fruit yield, and red fruit yield on total and pure live seed yield of 'Anaheim Chili' pepper grown for seed. Legend same as Fig. 1.

high total $\mathrm{N}$ level, indicated by the lower total and PLS seed yield for treatment 28-W compared with 70-5K (Fig. 6a). Total seed and PLS yields were more closely related to total applied $\mathrm{N}\left(R^{2}=0.893\right.$ and 0.851 , respectively) than total and red fruit yields $\left(R^{2}=0.393\right.$ and 0.658 , respectively). Both total seed and pure-live seed NUE decreased in a near linear fashion as total applied $\mathrm{N}$ increased and were not influenced by frequency of application (Fig. 3b). This result differs from the response for total and red fruit NUE, which did not decrease until $>240$ $\mathrm{kg} \mathrm{N} /$ ha was applied and was affected by frequency of application (Fig. 3a). The absence of a positive relationship between seed yield and $\mathrm{N}$ is contrary to the findings of Gill et al. (1974).

Leaf petiole $\mathrm{NO}_{3}-\mathrm{N}$ and its relationship with reproductive development and fruit and seed yield. Leaf petiole $\mathrm{NO}_{3}-\mathrm{N}$ generally increased rapidly within 1 week of application of $\mathrm{N}$ at 35 $\mathrm{kg} \cdot \mathrm{ha}^{-1}$ or more and then decreased the following week (Fig. 7). Weekly applications of $14 \mathrm{~kg}$-ha 1 maintained a relatively constant leaf petiole $\mathrm{NO}_{3}-\mathrm{N}$ status $<2000 \mathrm{mg} \cdot \mathrm{kg}^{-1}$, indicating a possible maintenance level of $\mathrm{N}$ required by the crop throughout the growing season. Weekly applications of $28 \mathrm{~kg} \cdot \mathrm{ha}^{-1}$ resulted in a gradual, steady increase in leaf petiole $\mathrm{NO}_{3}-\mathrm{N}$ through the season.

Each single application of $70 \mathrm{~kg} \cdot \mathrm{ha}^{-1}$ was adequate to raise the petiole $\mathrm{NO}_{3}-\mathrm{N}$ above $5000 \mathrm{mg}-\mathrm{kg}^{-1}$ (treatments $70-3 \mathrm{X}$ and 70-5 K). For three cycles of application, two consecutive weekly applications of $35 \mathrm{~kg} \cdot \mathrm{ha}^{-1}$ (treatment $35-5 \mathrm{~K}$ ) were needed to raise the petiole $\mathrm{NO}_{3}-\mathrm{N}$ to the $5000 \mathrm{mg} \cdot \mathrm{kg}^{-1}$ level. Single applications of this same amount (treatment $35-2 \mathrm{~K}$ ) were not suf-

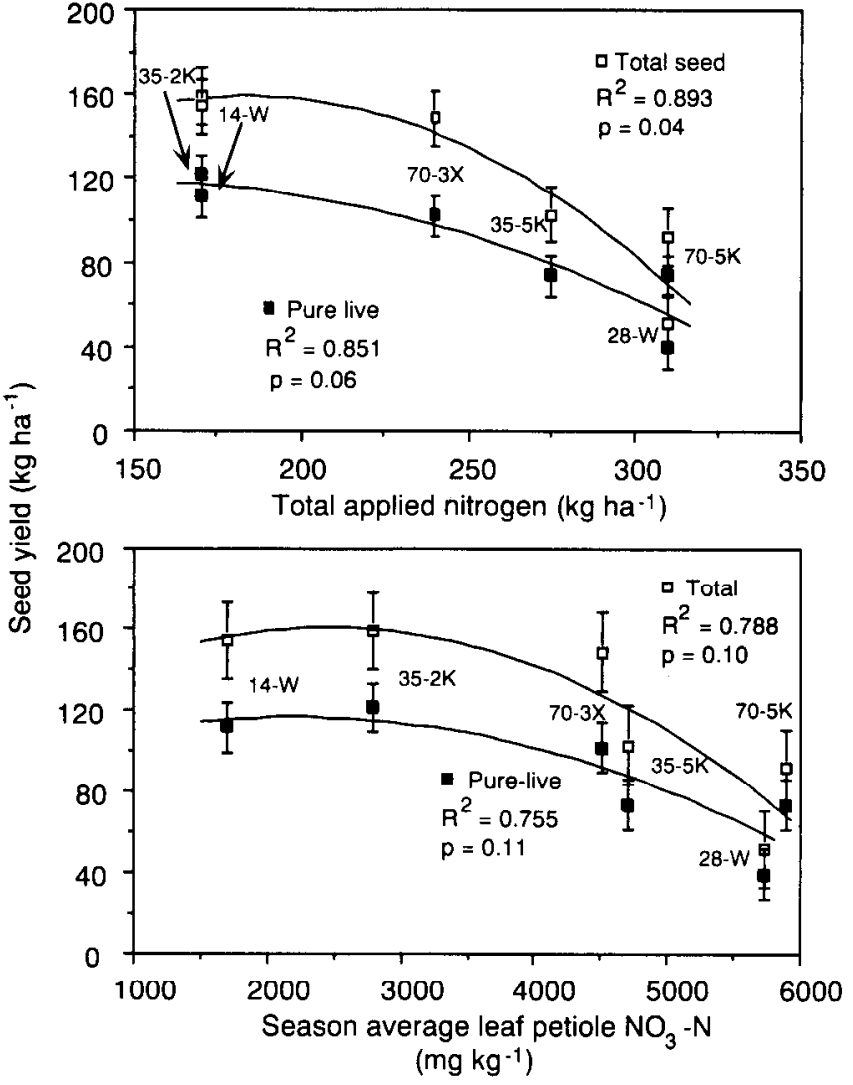

Fig. 6. Effect of total seasonal applied $\mathrm{N}$ and season average petiole $\mathrm{NO}_{3}-\mathrm{N}$ on total and pure live seed yield of 'Anaheim Chili' pepper grown for seed. Legend same as Fig. 1.

ficient to reach the $5000 \mathrm{mg} \cdot \mathrm{kg}^{-1}$ level at any time during the experiment, except for the $\mathrm{N}$ application during early plant establishment (day 184).

Previous research has reported critical plant tissue $\mathrm{NO}_{3}-\mathrm{N}$ levels of at least $4000 \mathrm{mg} \cdot \mathrm{kg}^{-1}$ to be necessary to maintain fruit yields (O'Sullivan, 1979; Panpruik et al., 1982). In this study, AVE $\mathrm{NO}_{3}-\mathrm{N}>4000 \mathrm{mg} \cdot \mathrm{kg}^{-1}$ were obtained with treatments $28-\mathrm{W}, 70-5 \mathrm{~K}, 70-3 \mathrm{X}$, and $35-5 \mathrm{~K}$ (Fig. 1). Treatments with AVE $\mathrm{NO}_{3}-\mathrm{N}$ values $>4500 \mathrm{mg} \cdot \mathrm{kg}^{-1}$ had total and pure-live seed yields lower than those treatments $<4000 \mathrm{mg} \cdot \mathrm{kg}^{-1}$ (with the exception of 70-3X PLS, which was intermediate to the two groups) (Fig. 6b). Treatment 28-W, the most detrimental treatment in regards to both fruit and seed production, had the second-highest $\mathrm{AVE} \mathrm{NO}_{3}-\mathrm{N}$ of all treatments. Treatment $70-3 \mathrm{X}$ had the highest total fruit yield and along with treatment $35-2 \mathrm{~K}$ the highest red fruit yields.

Overall, leaf petiole $\mathrm{NO}_{3}-\mathrm{N}$ was unrelated to number of flower buds, flowers, button fruit, and total fruit on the plant at any time during the experiment and therefore was not suitable as a predictor of reproductive status (data not shown). There was also no relationship between $\mathrm{AVE} \mathrm{NO}_{3}-\mathrm{N}$ and total or red fruit yield (data not shown). Treatment $70-5 \mathrm{~K}$ had the highest AVE $\mathrm{NO}_{3}-\mathrm{N}$ and received the same total amount of $\mathrm{N}$ as $28-\mathrm{W}$, but had a higher total and PLS yields (Fig. 6b). This substantiates that frequency of $\mathrm{N}$ application affects pepper plant growth. Treatments $14-\mathrm{W}$ and $35-2 \mathrm{~K}$ had the highest seed yields with treatment 70-3X intermediate to the higher and lower seed-yielding groups (Fig. 2).

These findings indicate that total seed and PLS yield are affected by both total applied $\mathrm{N}$ and frequency of application. 

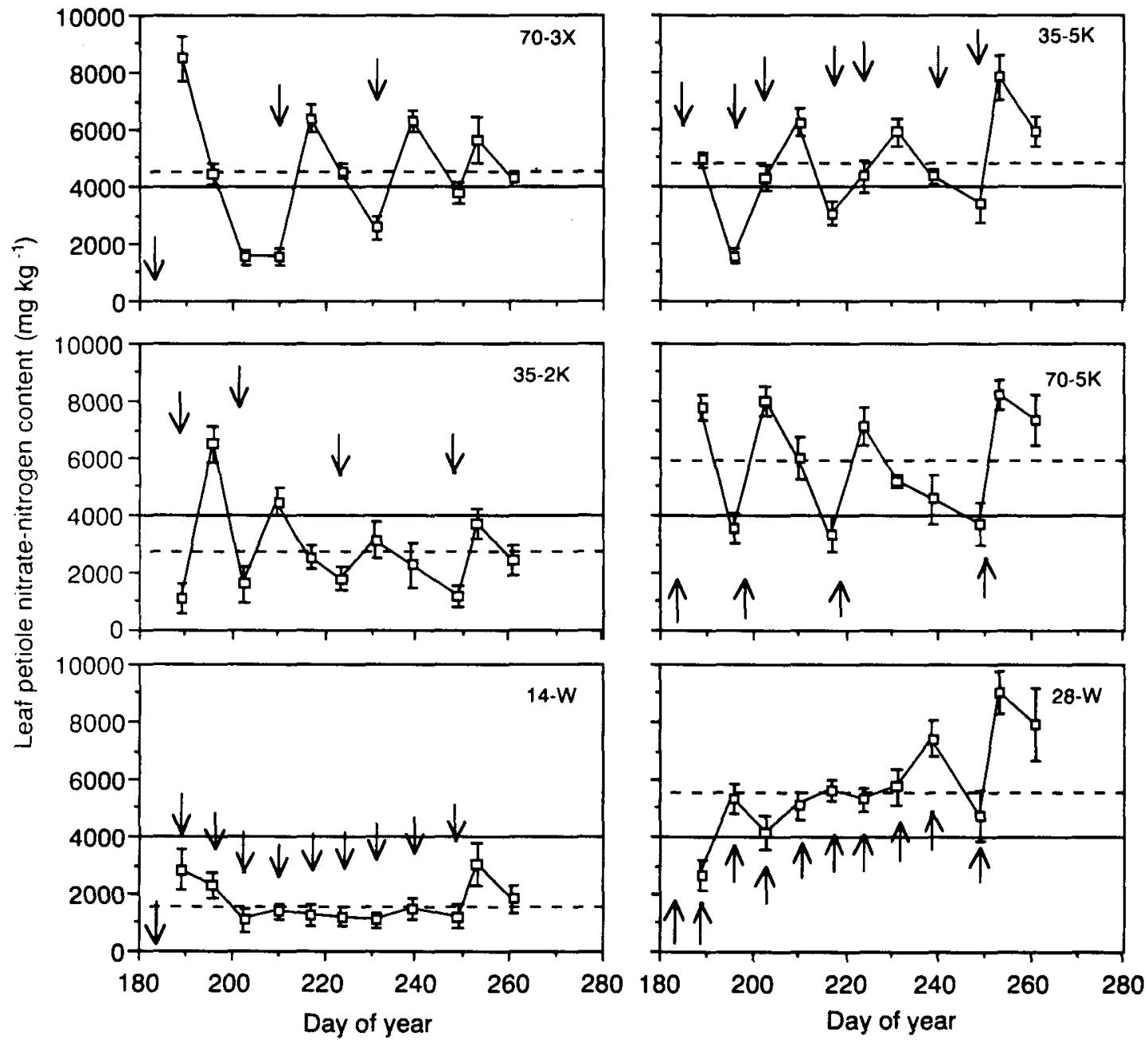

Fig. 7. Effect of six applied $\mathrm{N}$ treatments on leaf petiole $\mathrm{NO}_{3}-\mathrm{N}$ of 'Anaheim Chili' pepper grown for seed. Legend same as Fig. 1. Arrows and bars indicate time of $\mathrm{N}$ applications and SE of the means, respectfully. Dashed and solid lines indicate season average leaf petiole $\mathrm{NO}_{3}$ $\mathrm{N}$ and $4000 \mathrm{mg} \cdot \mathrm{kg}^{-1}$ levels, respectively.

Both total and red fruit production appear to be affected more by timing and frequency of $\mathrm{N}$ applications than by total seasonal applied N. Total fruit yield was maximized at $240 \mathrm{~kg} \mathrm{~N} / \mathrm{ha}$, while red fruit, total seed, and PLS yields decreased with increasing $\mathrm{N}$. The greatest efficiency of seed production was obtained from $170 \mathrm{~kg} \mathrm{~N} / \mathrm{ha}$ or with $\mathrm{AVE} \mathrm{NO}_{3}-\mathrm{N}$ values $<4000$ $\mathrm{mg} \cdot \mathrm{kg}^{-1}$ Different $\mathrm{N}$ management strategies should be considered to maximize seed yield and NUE compared to total fruit yield. Petiole $\mathrm{NO}_{3}-\mathrm{N}$ content can be used as an indicator of 'Anaheim Chili' pepper crop N status for seed production, but further research is needed to determine exact $\mathrm{N}$ fertility strategies needed for maximum seed production by this cultivar.

\section{Literature Cited}

Ahmed, M.K. 1984. Optimum plant spacing and nitrogen fertilization of sweet pepper in the Sudan Gezira. Acts Hort. 143:305-310.

Association of Offcial Seed Analysts. 1978. Rules for testing seeds. Stone Printing Company, Lansing, Mich.

Cochran, H.L. 1932. Factors affecting flowering and fruit setting in the pepper. Proc. Amer. Soc. Hort. Sci. 29:434+37.

Cochran, H.L. 1936. Some factors influencing growth and fruit-setting in the pepper (Capsicum frutescent L.). Cornell Agr. Expt. Sta. Memo. 190.
Copeland, L.O. and M.B. McDonald. 1985. Principles of seed science and technology. 2nd ed. Burgess, Minneapolis.

Gill, H. S., P.C. Thakur, and T.C. Thakur. 1974. Effect of nitrogen and phosphorus application on seed yield of sweet pepper (Capsicum arnnuum L.). Indian J. Hort. 31 :74-78.

Locascio, S.J. and J.G.A. Fiskell. 1977. Pepper production as influenced by mulch, fertilizer placement, and nitrogen rate. Proc. Soil \& Crop Sci. Soc. Florida 36:113-117.

Lorenz, O.A. and K.B. Tyler. 1983. Plant tissue analysis of vegetable crops, p. 24-29. In: H.M. Reisenauer (cd.). Soil and plant tissue testing in California. Div. of Agr. Sci., Univ. of California, Berkeley. Brd. 1879 .

Maynard, D. N., W.H. Lachman, R.M. Check, and H.F. Vemell 1962. The influence of nitrogen levels on flowering and fruit set of peppers. Proc. Amer. Soc. Hort. Sci. 81:385-389.

O'Sullivan, J. 1979. Response of peppers to irrigation and nitrogen. Can J. Plant Sci. 59:1085-1091.

Panpruik, P., B.D. McCaslin, and P.J. Wierenga. 1982. Effects of nitrogen and phosphorus fertilizer on yield and leaf content of trickle irrigated chili peppers. Res. Rpt. New Mexico Agr. Expt. Sta. 480.

Piazza, R. and G. Venturi. 1971. Effects of NPK fertilizer on peppers (Capsicum annuum L.) (In Italian). Riv. di Agron. 5:257-268.

Relwani, L.L. 1963. Fertilizer investigation in chili crop. Indian J. Agron. 7:291-299. 
Ririe, D. 1977. Chili pepper fertilization in Monterey County. Univ. of California Coop. Ext. Misc. Publ.

Sims, W.L. and P.G. Smith. 1984. Growing peppers in California. Leaflet 2676. Div. of Agr. Sci., Univ. of California, Berkeley.

Somos, A., F. Tarjanyi, and K. Juhasz. 1976. Effect of NPK fertilizer dosed gradually and in varying way on sweet pepper crop on its pigment content and yield. Kert. Egy. Kozl. (Egypt) 8:5-12.

Steiner, J.J. and B.F. Letizia. 1986. A seed-cleaning sluice for fleshyfruited vegetables from small plots. HortScience 21:1066-1067.

Stroehlein, J.L. and N.F. Oebker. 1979. Effects of nitrogen and phosphorus on yields and tissue analysis of chili peppers. Commun. Soil Sci. \& Plant Anal. 10:551-563.
Sundstrom, F. J., C.H. Thomas, R.L. Edwards, and G.R. Baskin. 1984. Influence of $\mathrm{N}$ and plant spacing on mechanically harvested Tabasco pepper. J. Amer. Soc. Hort. Sci. 109:642-645.

Thomas, J.R. and M.D. Heilman. 1964. Nitrogen and phosphorus content of leaf tissue in relation to sweet pepper yields. Proc. Amer. Soc. Hort. Sci. 85:419-425.

Thomas, J.R. and M.D. Heilman. 1967. Influence of moisture and fertilizer on growth and $\mathrm{N}$ and $\mathrm{P}$ uptake by sweet peppers. Agron. J. 59:27-30.

Wehner, T. C., G.E. Talla, and E.G. Humphries. 1983. A plot scale seed extractor for cucumber seeds. HortScience 18:246-247. 